\title{
Studi Awal Penentuan Sumber Sedimen DAS Cisadane Hulu dengan Radionuklida Alam
}

\section{Preliminary Study for Determination of Sediment Sources in Upper Cisadane Watershed by Using Enviromental Radionuclides}

\author{
Barokah Aliyanta, Nita Suhartini dan Bungkus Pratikno \\ Pusat Aplikasi Isotop dan Radiasi, BATAN \\ Jl. Lebak Bulus Raya No. 49 Jakarta Selatan 12440 \\ Email : barali@batan.go.id \\ Diterima 08-01-2015; Diterima dengan revisi 25-02-2015; Disetujui 15-05-2015
}

\begin{abstract}
ABSTRAK
Studi Awal Penentuan Sumber Sedimen DAS Cisadane Hulu dengan Radionuklida Alam. Pengembangan perunut untuk penentuan kontribusi sumber sedimen di daerah aliran sungai Cisadane telah dilakukan. Penentuan kontribusi sumber sedimen dilakukan dengan pengukuran kandungan radionuklida alam dalam tanah permukaan dan difokuskan pada daerah aliran sungai (DAS) Cisadane Hulu, yang terdiri dari sub DAS Cisadane Hulu dan sub DAS Cianten. Pengambilan sampel tanah permukaan $(0-2 \mathrm{~cm})$ dilakukan secara transek pada sumber sedimen potensial yaitu lahan olah, kebun campuran dan lapisan sub soil yang ada di ke dua sub DAS. Sedimen suspensi diambil di pertemuan aliran kedua sub DAS yaitu di Dusun Tamilung. Pengambilan sedimen suspensi hanya dilakukan satu kali dengan sampling selama 10 jam. Analisis kontribusi sedimen dilakukan berdasarkan persamaan multivariate mixing model dan statistik distribusi. Kontribusi sumber sedimen dari sedimen suspensi di Dusun Tamilung adalah 0-5,2 \%, 0,7-13,3\%, 0-4,2 \%, 1,2$19,4 \%, 28,5-55,5 \%$ dan 25,3-45,1\% masing-masing berasal dari kebun campuran di sub DAS Cianten, lahan olah di sub DAS Cianten, Kebun Campuran di sub DAS Cisadane Hulu, lahan olah di sub DAS Cisadane Hulu, Lapisan sub soil di sub DAS Cianten dan lapisan sub soil di sub DAS Cisadane Hulu.
\end{abstract}

Kata kunci : sumber sedimen, DAS Cisadane Hulu, proporsi kontribusi

\begin{abstract}
Preliminary Study for Determination of Sediment Sources in Upper Cisadane Watershed by Using Enviromental Radionuclides. Development of tracer to determine the contribution of sediment sources in the Upper Cisadane watershed has been done. Determining the source of sediment contribution was made through measurement of natural radionuclides content in the soil surface, sub-soil and in sediment suspension, and was focused on the Upper Cisadane watershed areas, which consist of sub-basin of Cianten and sub-basin of up-stream Cisadane. Sampling of soil surface $(0-2 \mathrm{~cm})$ was conducted transect on potential sources of sediment, namely cultivated land, mixed farmed and sub soil layers that exist in the two sub-basins. The sediment suspension was taken in confluence of two subbasins in Tamilung village. The sediment suspension was taken once during 10 hours. Analysis of the contribution of sediment was based on the equation of multivariate mixing model and the statistical distribution. Contributions sources of sediment in sediment suspension in Tamilung village was ranging from 0 to $5.2 \%$, from 0.7 to $13.3 \%$, from 0 to $4.2 \%$, from 1.2 to $19.4 \%$, from 28.5 to $55.5 \%$ and from 25.3 to $45.1 \%$ coming from mixed farms in Cianten sub-watershed, cultivated land in Cianten sub-watershed, Mixed farmed in Cisadane Hulu sub-watershed, cultivated land in Cisadane Hulu sub-watershed, sub-soil layer in Cianten sub-watershed and sub-soil layers in Cisadane Hulu sub-watershed, respectively.
\end{abstract}

Key words : sediment sources, Cisadane Hulu watershed, the proportion of contribution 


\section{PENDAHULUAN}

Keberadaan dan phenomena beban sedimen dalam aliran sungai merupakan proses alam yang merupakan bagian dari siklus adanya pelapukan, biokimia dan material tererosi dari kawasan daerah aliran sungai (DAS). Konsentrasi sedimen yang ada dalam aliran air baik kualitas maupun kuantitas dapat merubah kondisi lingkungan terkait dengan kesehatan, fungsi maupun resiliensi ekosistem aquatik [1]. Konsentrasi sedimen yang besar, secara fisika akan menimbulkan persoalan sedimentasi di daerah hilir, pendangkalan di badan sungai, waduk, bendung dan mengurangi daya tampung saluran air dalam kawasan tangkapan air. Ditinjau dari aspek debit aliran sungai, kondisi daerah aliran sungai dikatakan sehat bila memenuhi persyaratan seperti perbandingan debit saat musim hujan dan musim kemarau tidak lebih dari nilai ambang [2]. Fluktuasi debit aliran sungai antara musim hujan dan musim kemarau yang sangat jauh di atas nilai ambang, kejadian bencana alam seperti longsor, banjir dan kekeringan adalah indikator tidak optimalnya pengelolaan sumberdaya alam dalam daerah aliran sungai (DAS).

Pengelolaan DAS merupakan kegiatan memperbaiki, memelihara, dan melindungi kondisi DAS, agar dapat menghasilkan barang dan jasa yang berupa kontinuitas pemanfaatan sumberdaya lahan maupun air yang terkandung di dalamnya. Intervensi manusia dalam pemanfaatan sumber daya yang tidak berwawasan lingkungan membuat makin banyak DAS yang rusak karena terjadinya erosi dan hilang/ berkurangnya kemampuan untuk menyerap air. Kegiatan pertanian di daerah hulu yang tidak berbasiskan pada konservasi lahan dan air akan menyebabkan terjadinya percepatan laju erosi yang lebih besar dari proses terbentuknya tanah. Terjadinya erosi yang dipercepat ini akan berdampak pada lahan seperti menurunnya kesuburan, menurunnya daya serap air, dan berkurangnya daya tampung badan sungai, waduk untuk mengalirkan air dan naiknya biaya pengolahan air. Oleh karenanya, untuk mencapai keberhasilan pengelolaan DAS secara baik dan berhasil guna perlu diketahui informasi terkait dengan dinamika sedimen. Informasi tersebut mencakup sumber sedimen dan kontribusinya. Transportasi sedimen dari lokasi tanah tererosi sampai pada lokasi pengamatan suspensi bukanlah sekali kejadian saja, akan tetapi boleh jadi selama kurun waktu tertentu dan dalam kejadian yang berulangulang. Oleh karena itu, pada titik pengamatan sedimen suspensi semakin ke arah hilir, semakin banyak pula sumber potensial yang turut mengkontribusi. Informasi dinamika sedimen memberikan peran yang sangat penting untuk mengatasi permasalahan terkait dalam pengelolaan DAS secara menyeluruh.

Dewasa ini telah berkembang pesat pemanfaatan teknik sidikjari sedimen (sediment fingerprinting) untuk mengungkap hubungan antar sumber sedimen potensial dan sedimen yang berada pada kawasan hilir [4]. Teknik sidik jari sedimen ini telah banyak di aplikasikan di negara lain untuk meneliti kontribusi sumber potensial di berbagai skala spasial dari yang berukuran demplot dalam puluhan $\mathrm{m}^{2}$ [5], ratusan hektar [6] sampai lebih dari ratusan $\mathrm{km}^{2}$ [7]. Teknik sidikjari melalui sedimen ini, telah sukses digunakan oleh ROWAN J.S dkk sebagai alat untuk mengungkapkan hubungan antara praktek pengelolaan danau dan DAS untuk mengatasi masalah ledakan alga di Danau [8]. Teknologi sidikjari sedimen juga digunakan untuk memahami dinamika sedimen dalam river basin melalui karakteristik dan sifat-sifat sedimen [1]. Teknik ini juga telah sukses digunakan untuk mengidentifikasi sumber sedimen suspensi berapakah yang berasal dari lahan pertanian dan river bank erosi [9] dan untuk penentuan kontribusi sedimen berdasarkan karakteristik butiran sedimen halus pada sedimen suspensi $[10,11]$. Berbagai unsur/tracer yang sering digunakan sebagai sidikjari sedimen dapat digolongkan dalam beberapa jenis diantaranya radionuklida 
jatuhan, unsur tanah jarang, logam berat, kandungan anorganik, major utama ion, sifat magnetik tanah $[9,10,11]$ dan tracer oksida tanah jarang (rare earth oxide) [12].

Aktivitas radionuklida jatuhan pada tanah permukaan, umumnya cukup tinggi dan relatif rendah pada lapisan sub soil. Aktivitas radionuklida jatuhan pada berbagai tataguna lahan di tanah permukaan sendiri mempunyai perbedaan yang cukup signifikan akibat adanya erosi. Kenyataan demikian dapat dimanfaatkan untuk membedakan antara sumber-sumber sedimennya apakah dari lapisan tanah permukaan atau lapisan sub soil. Selain itu, sering juga aktivitas radionuklida jatuhan dapat dimanfaatkan untuk membedakan secara statistik antara karakteristik radionuklida pada sedimen yang berasal dari tanah ladang, kebun campuran maupun dari lapisan sub soil. Meskipun penelitian terkait dengan sidikjari sedimen telah banyak dilakukan di negara lain, namun demikian masih sangat jarang dilakukan di Indonesia.

Dengan gambaran di atas, dan berasumsikan bahwa radionuklida alam yang ada bersifat konservatif, tidak mengalami degradasi seperti halnya zat-zat organik, maupun proses alterasi kimia lain selama transportasinya dari daerah yang tererosi sampai di suatu titik pengamatan di lapangan dimana sedimen suspensi diambil, diharapkan dapat diestimasi besaran kontribusi dari masing-masing sumber sedimen potensial. Dengan kata lain, tujuan utama dari penelitian ini adalah memanfaatkan radionuklida alam (Pb-210 total, $\mathrm{Pb}-210$ supported dan Cs-137) sebagai sidikjari untuk menentukan kontribusi relatif sumber sedimen melalui distribusi frekuensi dari penyelesaian persamaaan sumber sedimen potensial dalam percampurannya. Untuk itu dilakukan sampling dan pengukuran aktivitas radionuklida alam yang ada pada sumbersumber sedimen potensial serta sedimen suspensi di outlet DAS Cisadane Hulu. Melalui analisis statistik penyelesaian multivariat mixing model dapat diestimasi besaran kontribusi sedimen dari sumbersumber sedimen potensial dimaksud.

\section{BAHAN DAN METODE}

\section{Lokasi penelitian}

Daerah penelitian meliputi daerah aliran sungai (DAS) Cisadane Hulu yang terdiri dari sub DAS Cisadane Hulu dan Sub DAS Cianteun. Di dalam kawasan ini termasuk dalam kawasan dengan kondisi lahan berlereng yang cukup curam dan curah hujan tahunan melebihi $3000 \mathrm{~mm}$ [2]. Variasi ketinggian DAS Cisadane Hulu sangat beragam dengan dominasi daerah yang berbukit dan bergelombang, dengan rentang ketinggian lahan yang disampling berkisar dari $400 \mathrm{~m}$ sampai $1000 \mathrm{~m}$ di atas permukaan laut. Di dalam sub DAS Cisadane Hulu maupun sub DAS Cianteun, dipertimbangkan sebagai sumber sedimen potensial yang mengalir ke sungai Cisadane sebagai sedimen suspensi, yang mana sedimen tersebut berasal dari lahan olah atau ladang, kebun dan sebagian perkebunan tak terawat yang selanjutnya diklasifikasikan sebagai kebun campuran serta lapisan sub soil tanah (jalan setapak, tampingan teras, erosi parit, penambangan dll).

\section{Pengumpulan sampel}

Contoh tanah permukaan diambil dari sumber sedimen potensial yang ada di daerah DAS Cisadane hulu secara transek yang mewakili lahan yang ada di lapangan. Lokasi pengambilan sampel tanah permukaan dibagi ke dalam 2 (dua) sub DAS yaitu dalam sub DAS Cisadane Hulu yang meliputi desa Cinagara, Tangkil, Cijeruk dan Tajur Halang, desa Tanjungsari dan Sukaharja; sub-sub DAS Cianten meliputi desa Barengkok, Cibeber, Ciasmara, Purwabakti, Cibunian, Purwasan, desa Gunung Picung, desa Nanggung dan desa Curug Bitung. Sedangkan sampel sedimen suspensi diambil di dusun Tamilung dengan koordinat $06^{\circ} 32,123^{\prime} \mathrm{S}$ dan $106^{\circ} 39,655 \mathrm{~T}$. 
Sampel tanah permukaan diambil dengan menggunakan alat scrapper dan alat
Cisadane Hulu dan sub DAS Cianten serta sedimen suspensi dapat dilihat pada Tabel 1 .

Tabel 1. Pengambilan sampel tanah dan sedimen di DAS Cisadane Hulu

\begin{tabular}{clc}
\hline Nomor & \multicolumn{1}{c}{ Sumber sedimen potensial dan lokasi } & Jumlah sampel \\
\hline 1 & Kebun campuran di sub DAS Cianten & 32 \\
2 & Ladang di sub DAS Cianten & 31 \\
3 & Kebun campuran di sub DAS Cisadane Hulu & 20 \\
4 & Ladang di sub DAS Cisadane Hulu & 61 \\
5 & Lapisan sub soil di sub DAS Cianten & 5 \\
6 & Lapisan sub soil di sub DAS Cisadane Hulu & 13 \\
7 & Sedimen suspensi di desa Tamilung & 1 \\
\hline
\end{tabular}

lain seperti cetok dalam beberapa luasan area sesuai dengan kondisi lahan dengan kedalaman 0-2 $\mathrm{cm}$ dan dikumpulkan dalam wadah plastik. Tiap sampel yang diambil merupakan sampel komposit dari beberapa titik pengambilan dalam transek. Sampel lapisan tanah sub soil diambil pada jalan setapak, tampingan teras, parit, dengan cara menyayat lapisan tanah pada sisi tampingan teras, parit dan jalan setapak. Sampel sedimen suspensi diambil menggunakan gayung ditampung dalam ember dengan volume kurang lebih $25 \mathrm{~L}$, ke dalam ember ditambahkan 2-3 g tawas dan diaduk. Setelah pengadukan, dibiarkan mengendap kurang lebih 30 menit dan sedimen yang mengendap dipisahkan dari air dan ditampung di wadah. Pengambilan sampel sedimen demikian diulang berkali-kali sampai jumlah keseluruhan sampel sedimen suspensi diperkirakan cukup untuk diukur dengan alat multi channel analyzer (MCA) di Laboratorium. Sampel sedimen suspensi selama kurang lebih 10 jam dari pagi sampai sore, setelah pada malam hari sebelumnya turun hujan. Titik-titik lokasi pengambilan sampel dapat dilihat pada Gambar 1, sedangkan pengambilan sampel tanah dan sedimen suspensi ditunjukkan pada Gambar 2. Jumlah sampel dari masing-masing sumber sedimen potensial sub DAS

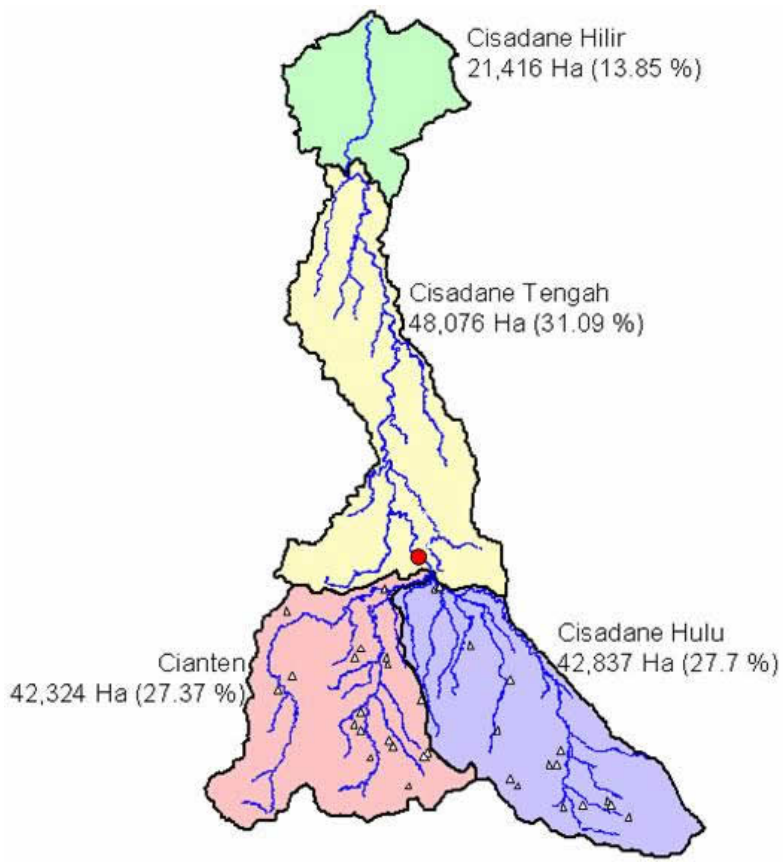

Gambar 1. Titik-titik lokasi pengambilan sampel pada DAS Cisadane Hulu (bulat merah adalah lokasi pengambilan sedimen suspensi)

Di Laboratorium, sampel tanah permukaan dan sedimen suspensi dikeringkan, digerus/dihaluskan dan ditimbang seberat 400 gram ditempatkan pada wadah khusus yang telah disiapkan. Sampel tersebut ditutup rapat dan disimpan selama kurang lebih sebulan sebelum 

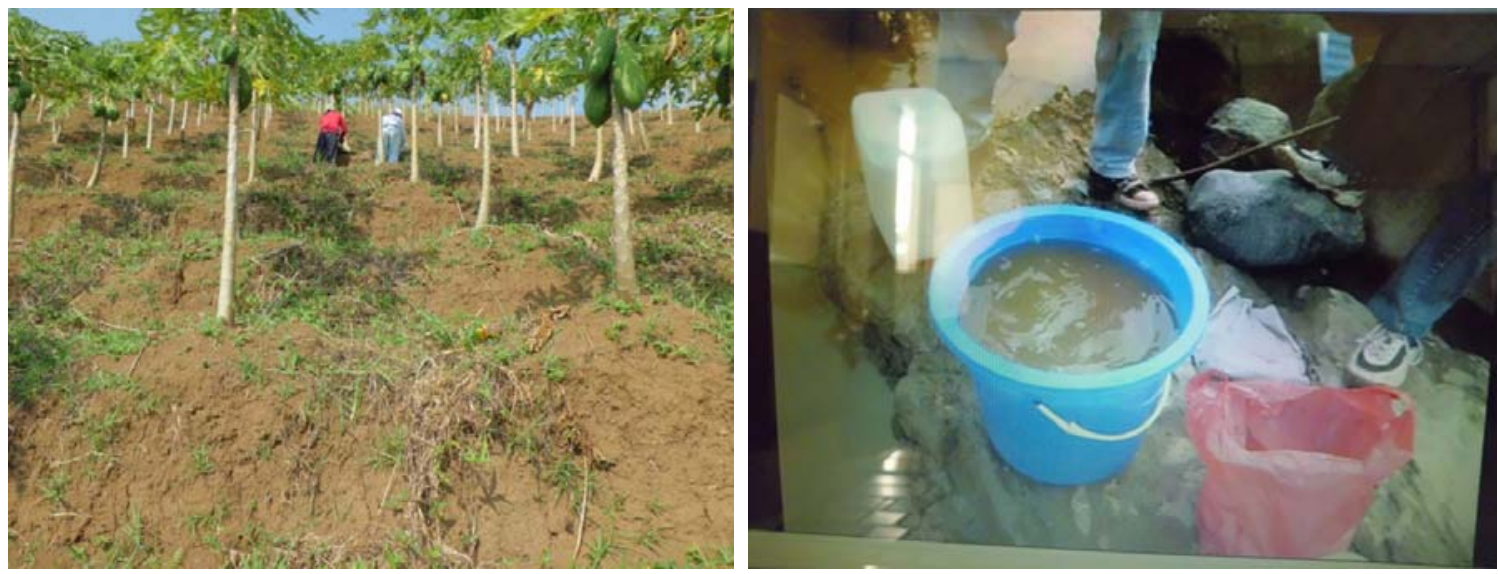

Gambar 2. Pengambilan tanah permukaan dan sedimen suspensi

dilakukan pengukuran kandungan $\mathrm{Pb}-210$ total, $\mathrm{Pb}-210$ supported dan $\mathrm{Cs}-137$ dengan MCA. Dimana, $\mathrm{Pb}-210$ total merupakan jumlah dari aktivitas $\mathrm{Pb}-210$ unsupported (jatuhan) dan $\mathrm{Pb}-210$ supported yang berasal dari masing-masing tanah serta Cs-137 merupakan radionuklida jatuhan akibat percobaan senjata nuklir.

\section{HASIL DAN PEMBAHASAN}

\section{Hasil pengukuran sumber sedimen potensial dan sedimen suspensi}

Hasil pengukuran aktivitas $\mathrm{Pb}-210$ total, $\mathrm{Pb}-210$ supported dan Cs-137 pada sumber sedimen potensial merupakan ratarata pengukuran dari jumlah total sampel pada masing-masing sumber seperti tertera pada Tabel 1. Hasil pengukuran dinyatakan secara statistik dalam bentuk nilai rata-rata dan standard error of the mean.

Dari hasil pengukuran pada kebun campuran di sub DAS Cianten diperoleh nilai $\mathrm{Pb}-210$ total bervariasi dari $29,58 \mathrm{~Bq} / \mathrm{kg}$ - 87,26 Bq/kg dengan rata-rata 57,01 Bq/kg dan standar error of the mean 2,71; nilai $\mathrm{Pb}$ 210 supported bervariasi dari $7,51 \mathrm{~Bq} / \mathrm{kg}$ $19,01 \mathrm{~Bq} / \mathrm{kg}$ dengan rata-rata $11,57 \mathrm{~Bq} / \mathrm{kg}$ dan standar error of the mean 0,48; nilai Cs137 bervariasi dari $0,45 \mathrm{~Bq} / \mathrm{kg}-1,37 \mathrm{~Bq} / \mathrm{kg}$ dengan rata-rata $0,87 \mathrm{~Bq} / \mathrm{kg}$ dan standar error of the mean 0,05 .
Dari hasil pengukuran pada ladang di sub DAS Cianten diperoleh nilai $\mathrm{Pb}-210$ total bervariasi dari 20,80 Bq/kg - 60,56 Bq/kg dengan rata-rata $38,61 \mathrm{~Bq} / \mathrm{kg}$ dan standar error of the mean 1,83; nilai $\mathrm{Pb}-210$ supported bervariasi dari $6,07 \mathrm{~Bq} / \mathrm{kg}-20,08 \mathrm{~Bq} / \mathrm{kg}$ dengan rata-rata $11,67 \mathrm{~Bq} / \mathrm{kg}$ dan standar error of the mean 0,56; nilai Cs-137 bervariasi dari tak terdeteksi sampai 2,64 Bq/kg dengan rata-rata $0,65 \mathrm{~Bq} / \mathrm{kg}$ dan standar error of the mean 0,09 .

Dari hasil pengukuran pada kebun campuran di sub DAS Cisadane Hulu diperoleh nilai $\mathrm{Pb}-210$ total bervariasi dari $32,78 \mathrm{~Bq} / \mathrm{kg}-101,54 \mathrm{~Bq} / \mathrm{kg}$ dengan rata-rata $61,1 \mathrm{~Bq} / \mathrm{kg}$ dan standar error of the mean 4,5 ; nilai $\mathrm{Pb}-210$ supported bervariasi dari 4,36 $\mathrm{Bq} / \mathrm{kg}$ - 15,33 Bq/kg dengan rata-rata 9,87 $\mathrm{Bq} / \mathrm{kg}$ dan standar error of the mean 0,75 ; nilai Cs-137 bervariasi dari 0,57 Bq/kg - 1,45 $\mathrm{Bq} / \mathrm{kg}$ dengan rata-rata $0,89 \mathrm{~Bq} / \mathrm{kg}$ dan standar error of the mean 0,07.

Dari hasil pengukuran pada ladang di sub DAS Cisadane Hulu diperoleh nilai $\mathrm{Pb}$ 210 total bervariasi dari $17,89 \mathrm{~Bq} / \mathrm{kg}$ $104,55 \mathrm{~Bq} / \mathrm{kg}$ dengan rata-rata $33,85 \mathrm{~Bq} / \mathrm{kg}$ dan standar error of the mean 1,72 ; nilai $\mathrm{Pb}$ 210 supported bervariasi dari $5,3 \mathrm{~Bq} / \mathrm{kg}$ $24,74 \mathrm{~Bq} / \mathrm{kg}$ dengan rata-rata $10,78 \mathrm{~Bq} / \mathrm{kg}$ dan standar error of the mean 0,48 ; nilai Cs137 bervariasi dari tak terdeteksi sampai $1,63 \mathrm{~Bq} / \mathrm{kg}$ dengan rata-rata $0,65 \mathrm{~Bq} / \mathrm{kg}$ dan standar error of the mean 0,04 . 
Nilai aktivitas berdasar analisis statistik sederhana tersebut dapat dilihat pada Tabel 2. Pada pengukuran sedimen suspensi tidak diberikan nilai standar error of the mean karena hanya dilakukan pengukuran sampel sekali. berperan dalam menghalangi terjadinya erosi percik sebagai proses awal terjadinya erosi lembaran. Dengan demikian, akan menyebabkan aktivitas radionuklida jatuhan dari $\mathrm{Pb}-210$ excess (jatuhan yang menempel di permukaan tanah) lebih rendah pada

Tabel 2. Hasil Analisis statistik pengukuran sampel

\begin{tabular}{clccc}
\hline \multirow{2}{*}{ No } & \multicolumn{1}{c}{ Jenis dan lokasi sampel } & \multicolumn{3}{c}{ Aktivitas (Bq/kg) } \\
\cline { 3 - 5 } & & Pb-210 total & Pb-210 supported & Cs-137 \\
\hline 1 & Kebun Campuran di sub DAS Cianten (CM) & $57,01_{(2,71)}$ & $11,57_{(0,48)}$ & $0,87_{(0,05)}$ \\
2 & Ladang di sub DAS Cianten (CC) & $38,61_{(1,83)}$ & $11,67_{(0,56)}$ & $0,65_{(0,09)}$ \\
3 & Kebun Campuran di sub DAS Cisadane Hulu & $61,1_{(4,5)}$ & $9,87_{(0,75)}$ & $0,89_{(0,07)}$ \\
& (CHM) & & & \\
4 & Ladang di sub DAS Cisadane Hulu (CHC) & $33,85_{(1,72)}$ & $10,78_{(0,48)}$ & $0,65_{(0,04)}$ \\
5 & Lapisan sub-soil di sub DAS Cianten (SSC) & $29,04_{(2,84)}$ & $14,74_{(1,46)}$ & $0,23_{(0,07)}$ \\
6 & Lapisan sub-soil di sub DAS Cisadane Hulu (SSH) & $21,93_{(2,98)}$ & $7,69_{(1,38)}$ & $0,15_{(0,03)}$ \\
7 & Sedimen suspensi di Tributari sub DAS, desa & 27,33 & 13,22 & 0,42 \\
& Tamilung & & & \\
\hline
\end{tabular}

Catatan: angka subscript adalah standard error of the mean

Jika tidak terjadi erosi, dapat dipastikan bahwa aktivitas radionuklida jatuhan Cs-137 dan $\mathrm{Pb}-210$ excess (Pb-210 total dikurang $\mathrm{Pb}-210$ supported) pada masing-masing sub DAS mempunyai nilai yang relatif sama. Perbedaan nilai yang terjadi karena besaran erosi yang berbeda dari keduanya. Secara umum, terlihat bahwa aktivitas $\mathrm{Pb}-210$ total dan Cs-137 pada kebun campuran lebih tinggi di banding dengan ladang, yang mengindikasikan bahwa erosi lembaran lebih tinggi terjadi di ladang. Hal ini sesuai dengan kejadian yang ada di lapangan bahwa pada kebun campuran tidak seluruh luasan lahannya diolah. Bila dibandingkan dengan lahan olahan (ladang), bila terjadi hujan lebat menjadikan lahan yang terolah tersebut mudah terjadi erosi percik dan larut terbawa dalam aliran permukaan. Erosi percik tentunya dimulai dari lapisan yang paling atas. Disamping itu, dibanding pada ladang yang relatif lebih terbuka untuk terkena tetesan curah hujan pada keseluruhan permukaan lahan yang terolah, maka naungan pohon utama sangat ladang karena tanah permukaan lebih banyak yang hilang terbawa aliran limpasan (erosi). Untuk aktivitas $\mathrm{Pb}-210$ supported tidak demikian. Hal ini karena aktivitas $\mathrm{Pb}$ 210 supported memang tidak dipengaruhi oleh faktor erosi akan tetapi tergantung dari tanah/batuan, sehingga aktivitasnya pada ladang dan kebun campuran mempunyai nilai yang relatif sama dalam ke dua sub DAS. Dengan kata lain untuk lapisan tanah permukaan $(0-2 \mathrm{~cm})$ aktivitas $\mathrm{Pb}-210$ supported pada kebun campuran dan ladang mempunyai nilai yang relatif sama.

Berdasarkan sub DAS, aktivitas radionuklida geogenic (Pb-210 total) lebih besar pada daerah sub DAS Cianteun dibandingkan pada sub DAS Cisadane Hulu. Namun demikian, dapat terlihat pada Tabel 2 bahwa aktivitas Cs-137 pada kedua sub DAS mempunyai nilai yang hampir sama. Dengan asumsi jatuhan global Cs-137 di kedua sub DAS sama dan pola tanam pada kebun campuran dan ladang yang juga relatif sama, maka memberikan dampak erosi yang relatif sama. Hal ini ditunjukkan dengan aktivitas Cs-137 pada masing-masing 
sub DAS baik di kebun campuran maupun di ladang.

Aktivitas radionuklida $\mathrm{Pb}-210$ total, $\mathrm{Pb}-210$ supported dan Cs-137 pada lapisan sub-soil jauh lebih kecil dibanding pada lapisan tanah permukaan di kebun campuran dan di ladang. Hal ini karena pada lapisan sub soil ini merupakan campuran dari sedikit material dari lapisan tanah permukaan dan lapisan tanah yang lebih dalam yang kurang mengandung radionuklida jatuhan seperti Cs-137 dan $\mathrm{Pb}$ 210 excess yang mengkontribusi dalam aktivitas $\mathrm{Pb}-210$ total. Dari Tabel 2 juga dapat diketahui bahwa aktivitas $\mathrm{Pb}-210$ supported (yang berasal dari tanah/batuan) dari lapisan sub soil memberikan nilai yang berbeda yang kemungkinan besar berasal dari kedalaman tanah yang berbeda juga. Dengan kata lain dapat dikatakan bahwa aktivitas $\mathrm{Pb}-210$ supported pada kedalaman lebih dari $2 \mathrm{~cm}$ mempunyai mempunyai aktivitas yang berbeda dengan lapisan permukaan pada kedalaman 0-2 $\mathrm{cm}$.

\section{Persamaan matematik untuk estimasi kontribusi sumber sedimen}

Untuk menghitung kontribusi dari masing-masing sumber sedimen potensial di dalam DAS Cisadane Hulu yang terdiri dari kebun campuran, ladang dan lapisan subsoil, digunakan model yang diperkenalkan oleh Mukundan yaitu multivariat mixing model [9]. Aktivitas radionuklida alam pada sedimen suspensi yang ada pada dusun Tamilung dengan koordinat $06^{\circ} 32,123^{\prime} \mathrm{S}$ dan $106^{\circ} 39,655 \mathrm{~T}$, merupakan hasil percampuran dari sedimen yang berasal dari 2 (dua) sub DAS yaitu sub DAS Cianten dan sub DAS Cisadane Hulu seperti dapat dilihat pada Gambar 1. Dimana sumber sedimen potensial hanya dibatasi dengan 3 sumber potensial pada masing-masing sub DAS yaitu kebun campuran, ladang dan lapisan subsoil, sehingga terhadap titik pengamatan sedimen suspensi terdapat 6 sumber sedimen potensial dengan 3 parameter sidik jari (Pb-210 supported, $\mathrm{Pb}-210$ total dan Cs137). Pada studi awal ini estimasi kontribusi sumber sedimen tidak memasukkan sumber sedimen potensial yang berasal dari akibat pencucian dari penambangan pasir yang ada di lapangan.

Konsep dan gambaran model mixing dapat ditulis dalam bentuk matrik berikut ini:

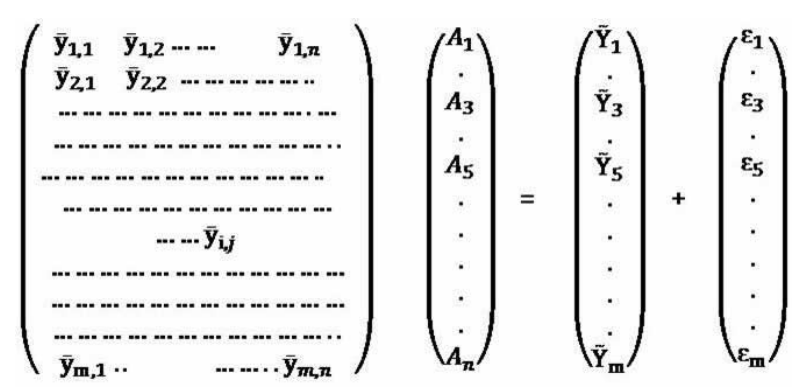

Dengan syarat batas dan parameterparameter sebagai berikut:

Jumlah $A_{j}\left(A_{1}, A_{2} \ldots A_{n}\right)=1$ (satu), dengan $A j$ adalah koefisien/prosentase kontribusi sumber sedimen $\mathbf{j}$, dan nilai masing-masing $A_{j}$ haruslah memenuhi $0 \leq A_{j} \leq 1 ; \quad \bar{y}_{i, j}$ adalah konsentrasi rata-rata komponen radionuklida $\mathrm{i}$ dalam sumber sedimen $\mathrm{j}_{i} \overline{\mathrm{Y}}_{\mathrm{i}}$ adalah konsentrasi komponen radionuklida $\mathrm{i}$ dalam sedimen suspensi dan $\varepsilon i$ adalah kesalahan least square terkait dengan komponen radionuklida $\mathrm{Y}_{\mathrm{i}}$. Persamaan matrik di atas dapat ditulis kembali dengan penyederhanaan bentuk sebagai berikut:

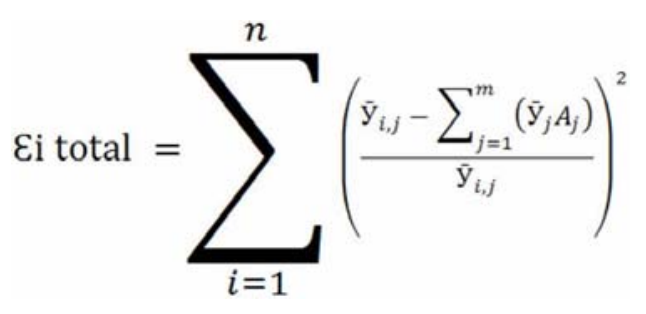

\section{Estimasi perhitungan kontribusi sumber sedimen}

Proses pengangkutan sedimen dari daerah hulu ke hilir bukanlah proses sekali event, akan tetapi proses yang berulang berkali-kali dengan berbagai faktor yang mempengaruhinya. Faktor pengaruh tersebut diantaranya adalah intensitas hujan yang menyebabkan adanya variasi aliran permukaan. Sedimen suspensi pada tributari sungai merupakan hasil campuran dari beberapa sumber sedimen dari sub DAS-sub DAS hulu. Berdasarkan hasil pengukuran 
radionuklida alam pada Tabel 2 dan persamaan di atas dapat dibuat 6 persamaan dengan 6 parameter (A1....A6) yang tidak diketahui untuk diselesaikan. Penentuan prosentase sumber sedimen disini tidak ditujukan untuk menentukan nilai absolut (nilai tunggal) dari sebuah persamaan matematis tersebut di atas yaitu dengan simulasi berdasarkan hasil $\mathcal{E}$ i total terkecil. Hal ini dipertimbangkan sesuai dengan kejadian proses pengangkutan sedimen dari sumber ke tempat pengambilan sampel yang bukan hanya sekali kejadian. Oleh karena itu, nilai prosentase tersebut ditentukan dengan menetapkan toleransi kesalahan 10 $\%$ terhadap aktivitas komponen radionuklida terukur pada sedimen suspensi. Penyelesaian persamaan tersebut dapat dilakukan melalui simulasi dengan menggunakan excell maupun menggunakan program iso source [13]. Dengan menggunakan program iso source tersebut dapat diperoleh proporsi masing-masing sumber sedimen melalui toleransi di atas dan diperoleh kombinasi penyelesaian dari 6 (enam) macam sumber sedimen sebanyak 541372 (limaratus empat puluh satu ribu tiga ratus tujuh puluh dua). Untuk menganalisis lebih lanjut, hasil dari sekian banyak kombinasi ini, dibuatkan grafik distribusi dalam bentuk proporsi kontribusi terhadap persen frekuensi. Distribusi masing-masing kontributor sumber sedimen dari sedimen suspensi dapat dilihat pada Gambar 3. Hasil estimasi kontributor ini menunjukkan bahwa ada begitu banyak kemungkinan nilai yang memenuhi, baik dalam bentuk yang mendekati distribusi normal maupun tidak.
Dari hasil penyelesaian yang terlihat pada Gambar 3 dan dengan tidak mempertimbangkan frekuensu, dapat dianalisis lebih lanjut bahwa proporsi kontribusi dari sumber sedimen yang berasal dari kebun campuran di sub DAS Cianten bervariasi dari 0 sampai $16 \%$, meskipun kemungkinan terjadinya kontribusi $16 \%$ ini sangat kecil (hanya 0,17 $\%)$. Demikian juga dengan kemungkinan kontribusi dari kebun campuran di sub DAS Cisadane Hulu bervariasi dari 0 sampai 14 $\%$, meskipun kemungkinan terjadinya kontribusi $14 \%$ ini juga sangat kecil (hanya 0,02 \%). Demikian juga halnya kontribusi dari lahan olah dari sub DAS Cianten bervariasi dari 0 sampai $38 \%$, meskipun peluang terjadinya kontribusi $38 \%$ sangat kecil (hanya 0,0185 \%).

Demikian seterusnya, oleh karena itu perlu dibuat gambar proporsi sumber sedimen potensial dengan memasukkan persen frekuensi seperti terlihat pada Gambar 3 sebagai sarana untuk menyatakan estimasi terbaik dengan tingkat ketidakpastian tertentu dibandingkan dengan harga absolut. Dengan mempergunakan geometric mean value diperoleh nilai estimasi dari masing-masing kontributor, dan dinyatakan sebagai nilai mean dengan tingkat ketidakpastian nilai dihitung berdasarkan pada standard deviasi terhadap mean seperti dapat dilihat dari Tabel 3.

Dari Tabel 3 dapat diketahui dengan jelas bahwa kontribusi terbesar dari sedimen suspensi yang berada di dusun Tamilung, yang merupakan tributari dari sub-DAS

Tabel 3. Hasil Estimasi Kontribusi Sumber Sedimen

\begin{tabular}{clc}
\hline No & \multicolumn{1}{c}{ Sumber sedimen } & Nilai estimasi kontribusi \\
\hline 1 & Kebun Campuran di sub DAS Cianten (CM) & $0,026 \pm 0,026$ \\
2 & Ladang di sub DAS Cianten (CC) & $0,070 \pm 0,063$ \\
3 & Kebun Campuran di sub DAS Cisadane Hulu (CHM) & $0,021 \pm 0,021$ \\
4 & Ladang di sub DAS Cisadane Hulu (CHC) & $0,103 \pm 0,091$ \\
5 & Lapisan sub-soil di sub DAS Cianten (SSC) & $0,420 \pm 0,135$ \\
6 & Lapisan sub-soil di sub DAS Cisadane Hulu (SSH) & $0,352 \pm 0,099$ \\
\hline
\end{tabular}



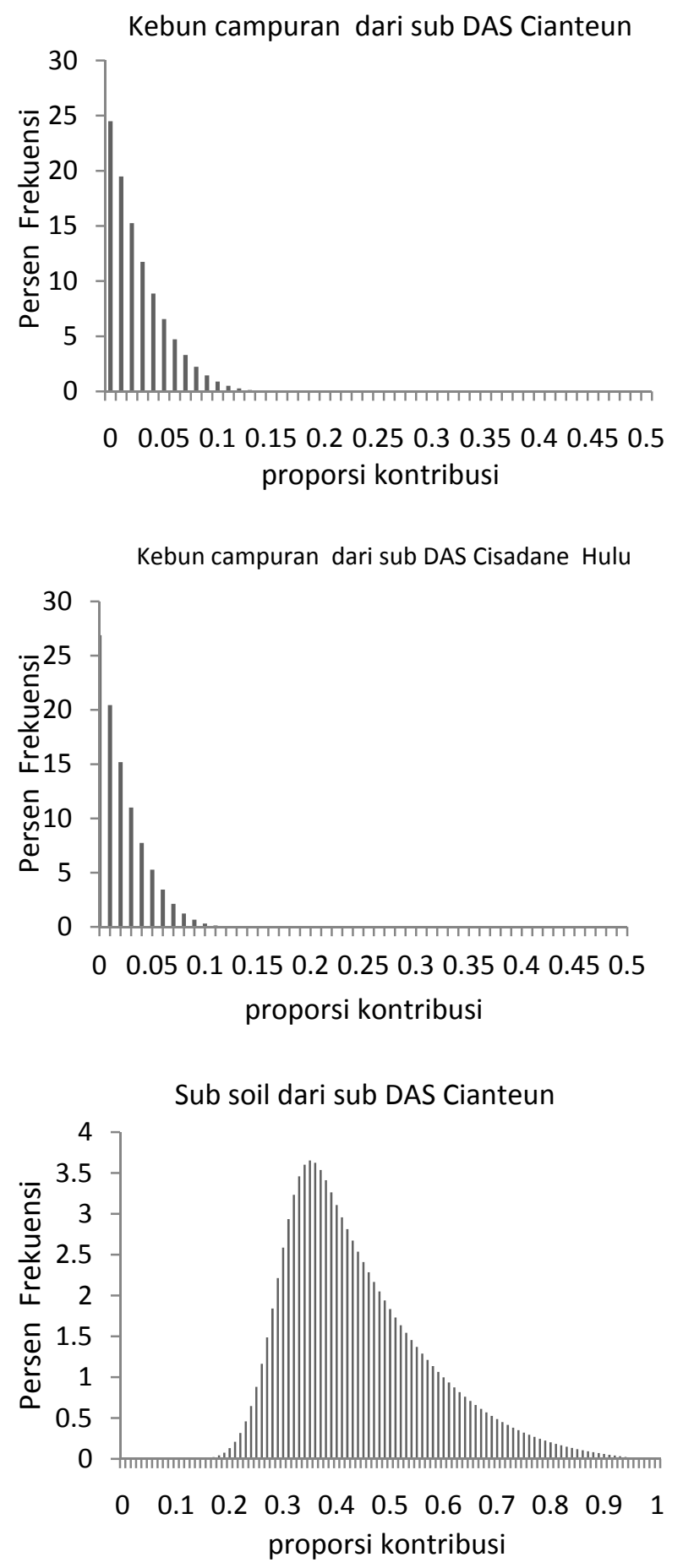
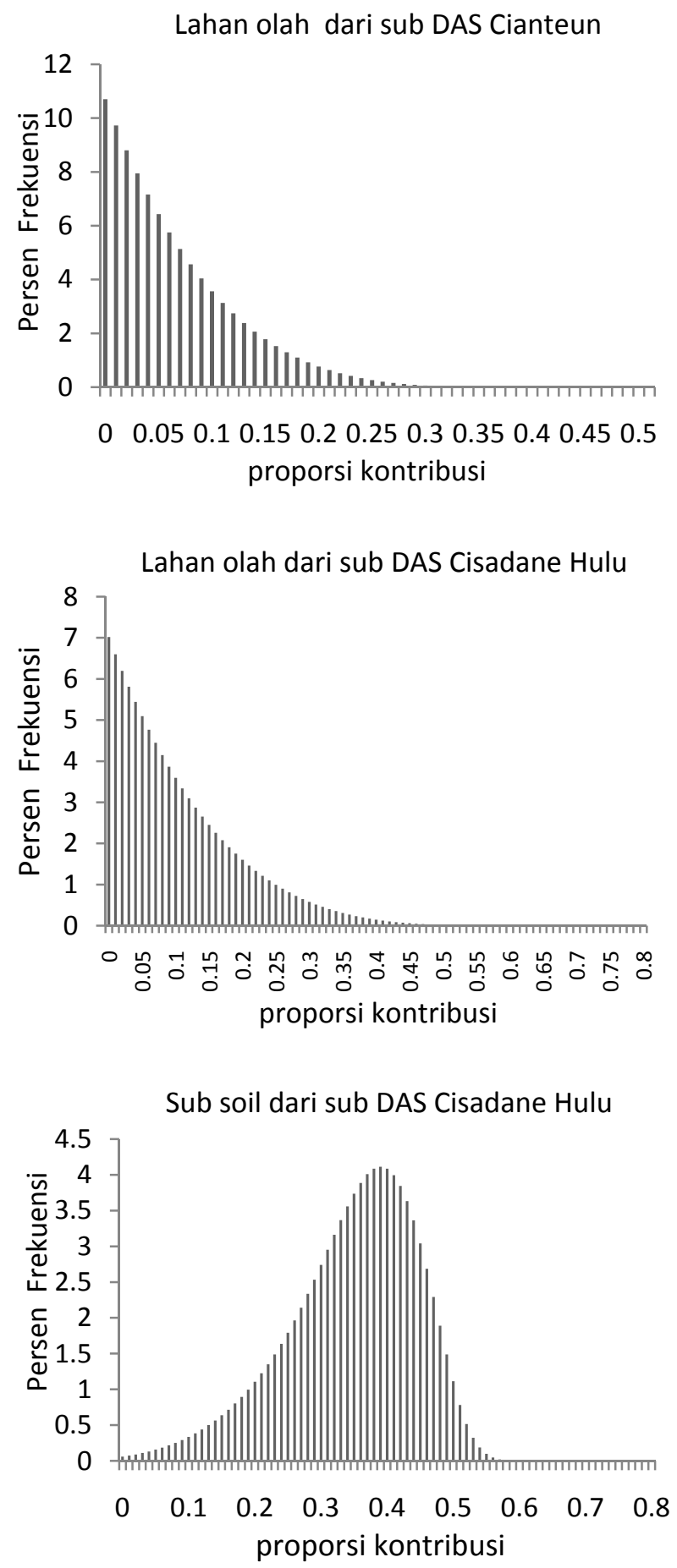

Gambar 3. Hasil perhitungan tiap kontributor dalam sedimen suspensi di Dusun Tamilung

Cianten dan sub DAS Cisadane Hulu adalah sedimen yang berasal dari lapisan sub-soil di sub DAS Cianten dan lapisan sub-soil di sub DAS Cisadane Hulu. Secara umum, dengan mempertimbangkan ketiga sumber sedimen di atas dapat dikatakan bahwa sedimen suspensi di Tamilung sebagian besar berasal dari lapisan sub-soil, diikuti dengan dari ladang dan kontributor terkecil berasal dari kebun campuran. Secara keseluruhan kontribusi dari masing-masing sumber adalah adalah $0-5,2 \% ; 0,7-13,3 \% ; 0-4,2 \%$; 
$1,2-19,4 \% ; \quad 28,5-55,5 \%$ dan $25,3-45,1 \%$ masing-masing berasal dari kebun campuran di sub DAS Cianten, lahan olah di sub DAS Cianten, Kebun Campuran di sub DAS Cisadane Hulu, lahan olah di sub DAS Cisadane Hulu, Lapisan sub-soil di sub DAS Cianten dan Lapisan sub-soil di sub DAS Cisadane Hulu. Adapun nilai mean estimasi dari keenam kontributor sumber sedimen tersebut adalah $2,6 \%$, dan $7 \% ; 2,1 \%$ dan $10,3 \%$ serta $42 \%$ dan $35,2 \%$ masingmasing untuk kebun campuran dan tanah olah di sub DAS Cianten, kebun campuran dan tanah olah di sub DAS Cisadane Hulu serta lapisan sub soil di sub DAS Cianten dan Cisadane Hulu.

\section{KESIMPULAN}

1. Aktivitas $\mathrm{Pb}-210$ supported yang berasal dari batuan/tanah dalam sub DAS Cianten lebih besar dibanding batuan/tanah dari sub DAS Cisadane Hulu.

2. Penelitian awal pengembangan perunut untuk penentuan kontribusi sedimen telah dilakukan melalui pengukuran radionuklida alam ( $\mathrm{Pb}-210$ total, $\mathrm{Pb}-210$ supported dan Cs-137) dari sumber sedimen potensial kebun campuran, ladang dan lapisan sub soil.

3. Penentuan kontribusi sedimen suspensi DAS Cisadane Hulu ditentukan melalui analisis statistik grafik persen frekuensi proporsi kontribusi dengan perhitungan geometric mean value.

4. Kontribusi sedimen suspensi dari sub-sub DAS Cisadane hulu diestimasikan 2,6\% dan $7 \% ; 2,1 \%$ dan $10,3 \% ; 42 \%$ dan $35,2 \%$ masing-masing untuk kebun campuran dan tanah olah/ladang di sub DAS Cianten, kebun campuran dan tanah olah/ladang di sub DAS Cisadane Hulu serta lapisan sub soil di sub DAS Cianten dan Cisadane Hulu.

\section{UCAPAN TERIMA KASIH}

Penulis mengucapkan banyak terima kasih kepada seluruh staf teknis group
Sedimentologi-PAIR atas bantuan melakukan perlakuan sampel yang telah diambil dan penyiapan peralatan lapangan lain. Penulis juga mengucapkan banyak terima kasih kepada para reviewer dengan segala koreksi dan masukannya, sehingga karya tulis ini dapat dipublikasikan.

\section{DAFTAR PUSTAKA}

1. KOITER A. J, et al., The Behaviour Characteristics of Sediment Properties and Their Implications for Sediment Fingerprinting as an Approach for Identifying Sediment Sources in River Basin, Earth Science Reviews, 125, 24-42 (2013).

2. Laporan Akhir Pengelolaan DAS Cisadane Terpadu tahun 2010, BP DAS Citarum Ciliwung, (2010).

3. GUZMAN, G., et al., Sediment tracers in water studies: current approach and challenges, Journal of Soils Sediment, 13, 816-833 (2013).

4. WILSON, H., CRUSE, R. And BURRAS, L., A method to adapt watershed scale sedimen fingerprinting techniques to small-plot run-off experiment, Journal of Soil and Water Conservation, 66, 323-328 (2011).

5. YANG, M.Y., et al, Partitioning the contribution of sheet and rill erosion using Berllium-7 and Cesium-137, Soil Science American Journal, 70, 1579-1590 (2006).

6. KOUHPEIMA, A., et al, Using Sediment Deposited in Small Reservoirs to Quantify Sediment Yield in Two Small Catchments of Iran, Journal of Sustainable Development, 3 (3), September (2010). 
7. SMITH, H.G and BLAKE W.H., Sediment Fingerprinting in Agricultural Catchments: A critical re-examination of source discrimation and data correction", Geomorphology, 201， 177-191 (2014).

8. ROWAN J.S, BLACK S, and FRANKS S.W, Sediment fingerprinting as an Environmental Forensics Tool Explaining Cyanobacteria Bloom in Lakes, Apllied Geology, 32, 832-843 (2012).

9. MUKUNDAN R., et al, Sediment fingerprinting to determine the source of suspended sediment in a southern piedmont stream, Journal Environment Quality, 39, 1328-1337 (2010).

10. C.G ALLEN and B. NOE GREGORY, Sediment source analysis in the linganore creek watershed, Maryland USA Using the Sediment
Fingerprinting Approach, 20082010, Journal of Soils Sediments, 1735-1753 (2013).

11. HADDADCHI, A., et al, Sediment fingerprinting in fluvial systems:review of tracers, sediment sources and mixing models, International Journal of Sediment Research, 28, 560-578 (2013).

12. DEASY, C and QUINTON, J.N., Use of rare earth oxides as tracers to identify sediment source areas for agricultural hillslopes, Solid Earth, 1, 111-118 (2010).

13. NUKURAGI TAIHORO, Protocol on the use of the CSSI Technique to Identify and Apportion Soil Sources from Land use, prepared for joint FAO/IAEA Division of Nuclear Techniques in Food and Agriculture, January, (2014) (www.niwa.co.nz). 
Jurnal Ilmiah Aplikasi Isotop dan Radiasi

A Scientific Journal for The Applications of Isotopes and Radiation

Vol. 11 No. 1 Juni 2015 